DOI: 10.26693/jmbs05.03.068

UDC 616.24-002-056.5

Kuznetsova L. ${ }^{1}$, Gopko O. ${ }^{2}$, Savchenko L..

\title{
MARKERS OF SYSTEMIC INFLAMMATION IN COPD PATIENTS WITH OBESITY
}

\author{
${ }^{1}$ SI "Zaporizhia Medical Academy of Post-Graduate Education Ministry \\ of Health of Ukraine", Ukraine \\ ${ }^{2}$ Ukrainian Medical Stomatological Academy, Poltava, Ukraine
}

olgopko@gmail.com

Chronic obstructive pulmonary disease is one of the most common respiratory diseases in which comorbid pathology is detected in almost $90 \%$ of patients. Particular attention in the clinic of internal medicine deserves a coexisting with alimentary obesity due to the following risk factors: population aging, hypodynamia, over-nutrition, which contributes to the progression of comorbid pathology and the development of complications.

The chronic inflammatory process is the main link in the pathogenesis of chronic obstructive pulmonary disease, which causes structural changes of the respiratory tract and lungs (bronchial obstruction and loss elasticity of the lung parenchyma) against the background of systemic inflammation, especially in overweight patients.

So, the purpose of the work was to analyze literature data on the common markers of systemic inflammation in chronic obstructive pulmonary disease patients with obesity.

High sensitivity C-reactive protein is an acutephase protein synthesized mainly by hepatocytes in response to the bronchopulmonary tissue damage by the inflammatory process. The research has demonstrated the relationship between the high sensitivity Creactive protein and functional ventilatory capacity, clinical chronic obstructive pulmonary disease severity.

Adipose tissue is considered as an endocrine organ and a source of biologically active substances: adipokines, bioactive peptides, free fatty acids, monocytic chemotactic factor-1 (monocyte chemotactic protein-1), pro-inflammatory cytokines, involved in systemic inflammation in many pathological conditions, including respiratory diseases. There are many works focused on the study of leptin as a pleiotropic hormone determining the state of immune homeostasis and angiogenesis. However, a remarkable discovery was the determination of the leptin role in the respiratory tract. Leptin is a stimulator of ventilation, a factor determining the processes of maturation and development of the lungs, as well as respiratory diseases, including obstructive sleep apnea syndrome, bronchial asthma, chronic obstructive pulmonary disease and lung cancer. It should be noted that leptin is involved in airway inflammation in chronic obstructive pulmonary disease, possibly due to the regulation of infiltration and apoptosis of immune cells in the submucosal basis of the bronchi.

Conclusion. Thus, obesity has a significant effect on the intensity of systemic inflammation in patients with chronic obstructive pulmonary disease. High sensitivity C-reactive protein and leptin are the common biomarkers of systemic inflammation that can be used to assess the severity of chronic obstructive pulmonary disease and obesity.

Keywords: chronic obstructive pulmonary disease, obesity, high sensitivity C-reactive protein, leptin.

Research relation to the programs, plans, and department themes. This work was supported by Ukrainian Medical Stomatological Academy, Poltava, Ukraine "Improvement of diagnostic approaches and treatment optimization of digestive diseases in combination with other diseases of the body systems", Fundamental research project, State registration No $0117 \cup 000300$.

Introduction. The chronic inflammatory process is the main link in the pathogenesis of chronic obstructive pulmonary disease (COPD). It causes structural changes in the respiratory tract and lungs (bronchial obstruction and loss elasticity of the lung parenchyma) against the background of systemic inflammation, especially in overweight patients, given the significant contribution of fat cells to the inflammatory process [1, $2,3]$.

So, the purpose of the work was to analyze literature data on the common markers of systemic inflammation in COPD patients with obesity.

It is common knowledge that the main mechanisms of inflammation in COPD are an increasing number of alveolar macrophages, neutrophils, Tlymphocytes (mainly T-helper cells (Th1 and Th17). These mechanisms, together with epithelial, endothelial cells, and fibroblasts, express the synthesis of 
pro-inflammatory mediators such as cytokines, chemokines, growth factors, and lipid mediators [4]. It is considered that T-lymphocytes play an essential role in the pathogenesis of COPD. However, the mechanisms of this inflammatory process remain understudied. One of the researches found that the blood of COPD patients demonstrated a higher expression of CC chemokine 5 receptors (CCR5) on CD8 + T cells in bronchoalveolar lavage and a higher percentage of CXCR3 + CD8 + T lymphocyte cells, as compared to apparently healthy individuals. Moreover, the results obtained were dependent on the gender of the patients. The Th1 / Tc1 immune response was associated with macrophages and neutrophil density in the bronchi, and the reaction of Th2 / Tc2 was associated with the severity of emphysema [5].

Two large-scale COPD Gene and ECLIPSE studies (total of 6299 participants) are devoted to the relationship between changes in circulating immunocompetent cell populations and COPD severity and progression. The results of these studies suggested a positive correlation between $\mathrm{FEV}_{1}$ and lymphocyte counts against the feedback with myeloid cell counts (neutrophils, monocytes). The number of lymphocytes, monocytes, and eosinophils determined the three-year change in spirometric parameters of airflow limitation. In COPD patients, a decreased number of CD4 + memory cells and naive B cells was observed, suppressing the maturation of lymphocytes against the background of enlargement of myeloid cells. This fact indicates an essential place of immune mechanisms in the pathogenesis of COPD progression [6].

Most studied mediators of chronic inflammation in COPD patients are inflammatory interleukins (IL-1, IL-2, IL-6, IL-8, IL-9, IL-12, IL-18), tumor necrosis factor-alpha (TNF- $\alpha$ ), high sensitivity C-reactive protein (hsCRP), matrix metalloproteases. They also include specific markers, namely desmosine isomers, leukotriene-B4, neutrophil elastase and surfactant protein $D$, natriuretic peptide (NT-proBNP), and T-troponin [7, 8, $9,10]$.

The hsCRP is a recognized biomarker of systemic inflammation, synthesized mainly by hepatocytes in response to the bronchopulmonary tissue damage by the inflammatory process [11]. The hsCRP binds phagocyte receptors and plays a role in cell apoptosis, correlating with other inflammatory mediators, particularly with IL-6, IL-1 [12].

It is essential to determine the dependence of the hsCRP concentration and the number of COPD exacerbations, which determine the prognosis of the disease. The obtained data are contradictory, as evidenced by the results of research, which did not show a significant correlation between the hsCRP concentration and the number of exacerbations. Other stud- ies found a significant correlation between the hsCRP concentration and the number of exacerbations, identifying hsCRP as a marker for the development of COPD exacerbations [13, 14].

In the study, which involved 116 patients in the stable phase of COPD and 35 practically healthy individuals, the researchers found that serum hsCRP concentration was significantly higher in COPD patients than in practically healthy individuals $(4.48 \pm 0.83$ vs. $1.1 \pm 0.27 \mathrm{mg} / \mathrm{I} ; \mathrm{p}<0,05)$. Noteworthy the conclusion that serum hsCRP concentration $>3 \mathrm{mg} / \mathrm{l}$ has a negative effect on COPD prognosis compared to hsCRP concentration $\leq 3 \mathrm{mg} / \mathrm{I}$ (odds ratio $(\mathrm{OR})=2.71$; $95 \%$ confidence interval $(\mathrm{Cl})=1.05-6.99 ; \mathrm{p}<0.05)$. The results of four studies (1750 patients with COPD), which provided statistically similar results $(O R=1.54$; $95 \% \mathrm{Cl}=1.14-2.07 ; \mathrm{p}<0.01)$, confirmed this statement. These studies emphasized the importance of identifying the hsCRP biomarker in patients with stable COPD [15].

A systematic review and meta-analysis, conducted to clarify the relationship between hsCRP concentration and COPD mortality, included 15 sources on COPD mortality. In the general analysis, increase the concentration of hsCRP was significantly associated with the mortality rate $(\mathrm{OR}=1.53,95 \% \mathrm{Cl}=1.32-1.77$; $p<0.001)$. However, it is necessary to observe that this relationship was established at maximal indices of hsCRP and primarily in the Asian population of COPD patients [16].

Considering that systemic inflammation is the primary pathogenetic mechanism of COPD with obesity, the question remains about the role of adipose tissue in the progression of the inflammatory process, the intensity of which depends on the patient's body mass index (BMI). According to a randomized ECLIPSE trial, systemic inflammation activity was significantly higher in patients with BMI $29.4 \mathrm{~kg} / \mathrm{m}^{2}$ compared to the group of patients where BMI was within normal limits. The scholars also found that $30 \%$ of COPD patients had no manifestations of systemic inflammation both in the initial stage of the disease and after one year of observation against the background of availability bronchial obstructive syndrome. The results of this study also demonstrated a correlation between inflammatory marker concentration and hypodynamia, especially in COPD patients with obesity, which contributes to the growth of pro-inflammatory markers [17, 18].

The results of the research by $\mathrm{R}$. Agarwal et al., 2013 [19] proved that BMI had an inverse correlation with serum hsCRP concentration. According to another study, COPD patients with obesity had an increased serum hsCRP concentration compared to COPD patients with normal BMI [20]. The study by 
M. Breyer et al., 2009, confirmed that in COPD patients with $\mathrm{BMI} \geq 30 \mathrm{~kg} / \mathrm{m}^{2}$ serum hsCRP concentrations was by 3.3 times higher $(95 \% \mathrm{Cl}, 1.5-7.0 ; \mathrm{p}=$ $0.002)$ than in patients with BMI $21-24.9 \mathrm{~kg} / \mathrm{m}^{2}$. However, in COPD patients with low BMI $\left(<21 \mathrm{~kg} / \mathrm{m}^{2}\right)$, hsCRP concentration was by 2 times higher (OR = $0.5 ; 95 \% \mathrm{Cl}=0.3-0.9 ; \mathrm{p}=0.022$ ) compared with control groups (BMI within normal limits) [21].

Today, adipose tissue is considered an endocrine organ and a source of biologically active substances. These substances include adipokines, bioactive peptides, free fatty acids, monocytic chemotactic factor-1 (monocyte chemotactic protein -1 (MCP-1)), and proinflammatory cytokines (IL-1 $\beta$, TNF- $\alpha$, hsCRP, IL-6). They are the modulators of cardiovascular function, insulin sensitivity, inflammation, and function of adipose tissue against the background of inhibition of production the anti-inflammatory mediators [22, 23]. Adipokines can also be synthesized by inflammatory cells, participating in systemic low-intensity inflammation in many pathological conditions, including respiratory diseases (COPD, bronchial asthma, interstitial lung diseases) [24]. Thus, adipose tissue plays a vital role in the processes of systemic inflammation and the formation of carbohydrate metabolism disorders in COPD patients. It acts as an independent factor in the potentiation of the bronchopulmonary inflammatory process.

Leptin is involved in many vital functions of the body. These functions include energy metabolism, reproductive function, and angiogenesis. It also participates in the expression of cytokines synthesized by immunocompetent cells and regulates the processes of cell apoptosis, involved in the regulation of T-cell proliferation. Furthermore, leptin can activate macrophages and promote vascular proliferation. The regulation of leptin synthesis occurs through the hypothalamus-pituitary-adrenal axis and depends on the body fat mass. Leptin activates the synthesis of proinflammatory cytokines such as IL-2, interferon-y produced by Th1, and inhibits the synthesis of IL-4 synthesized by Th2 [25, 26, 27, 28].

An important discovery was the determination of the leptin role in the respiratory tract. Leptin is a stimulator of ventilation, a factor determining the processes of maturation and development of the lungs, as well as respiratory diseases, including obstructive sleep apnea syndrome, bronchial asthma, COPD, and lung cancer [29, 30].
Scientific evidence suggests that leptin is involved in airway inflammation in COPD, possibly due to the regulation of infiltration and apoptosis of immune cells in the submucosal basis of the bronchi. Increased leptin concentration in the proximal airways correlates with the expression of activated $T$ lymphocytes (mainly CD8 +) and the absence of apoptotic T cells. Leptin concentration in the induced sputum positively correlated with inflammatory markers. However, the question remains debatable on the existence of a paracrine cross-section between resident lung epithelial cells and immune cells in response to harmful particles, requiring further scientific studies on the role of leptin in the pathogenesis of COPD [27, 29, 31, 30, 32, 33].

Leptin concentration in COPD patients depends on BMI. The studies confirmed this fact by demonstrating a close relationship between serum leptin concentration and TNF-á content and soluble TNF receptor (sTNF-R55 and -R75) and a direct correlation with $\mathrm{BMI}$ and body fat percentage (\% of fat) in patients with COPD [34, 35, 36].

Another study found a link between genetic variants in the leptin- $R$ gene and decreased lung function in COPD patients showed a significant association ( $p$ $<0.05$ ). Haplotype analyzes confirmed some of these associations, identified by distinct markers, suggesting that genetic variants in the leptin- $R$ gene are significantly associated with decreased lung function in the COPD smoker population. The results confirmed the genetic nature of the leptin effect on the severity of ventilatory capacity in COPD patients. They may identify leptin-R as a new gene candidate for COPD [37].

The purpose of one study was to evaluate the relationship between leptin levels in COPD patients and changes in respiratory function depending on his concentration. Analysis of the results of this study revealed an increase in leptin concentration in COPD patients with overweight and obesity compared to patients with normal body weight $(p<0.01)$. The research found the most pronounced obstructive and restrictive changes in patients with hyperleptinemia, and its level is closely related to the degree of bronchial obstruction [38].

Conclusion. Thus, in COPD patients, obesity has a significant effect on the intensity of systemic inflammation. The hsCRP and leptin are markers of this inflammation and, therefore, can be used to assess the severity of COPD and obesity.

\section{References}

1. Samuleeva YuV, Zadyonchenko VS, Ly VV, Adasheva TV, Samorukova EY, Pykhlak AE, et al. Ozhirenie i metabolicheskie narusheniya u bolnykh khronicheskoy obstruktivnoy boleznyu legkikh: vozmozhnosti fenotipirovaniya. Pulmonologiya. 2014; (5): 32-8. https://doi.org/10.18093/0869-0189-2014-0-5-32-38 [Russian] 
2. Barnes PJ. Cellular and molecular mechanisms of chronic obstructive pulmonary disease. Clin Chest Med. $2014 ; 35$ (1): 71-86.

3. Vanfleteren LE, Spruit MA, Groenen M, Gaffron S, van Empel VP, Bruijnzeel PL, et al. Clusters of comorbidities based on validated objective measurements and systemic inflammation in patients with chronic obstructive pulmonary disease. Am J Respir Crit Care Med. 2013; 187(7): 728-35. doi: 10.1164/rccm.201209-1665OC

4. Barnes PJ. Inflammatory mechanisms in patients with chronic obstructive pulmonary disease. J Allergy Clin Immunol. 2016; 138(1): 16-27.

5. Forsslund H, Yang M, Mikko M, Karimi R, Nyrén S, Engvall B, et al. Gender differences in the T-cell profiles of the airways in COPD patients associated with clinical phenotypes. Int J Chron Obstruct Pulmon Dis. 2016; 12: 35-48. doi: 10.2147/COPD.S113625

6. Halper-Stromberg E, Yun JH, Parker MM, Singer RT, Gaggar A, Silverman EK, et al. Systemic Markers of Adaptive and Innate Immunity Are Associated with Chronic Obstructive Pulmonary Disease Severity and Spirometric Disease Progression. Am J Respir Cell Mol Biol. 2018; 58(4): 500-9. doi: 10.1165/rcmb.2017-03730C

7. Brekke $\mathrm{PH}$, Omland T, Holmedal SH. Troponin-T elevation and long-term mortality after chronic obstructive pulmonary disease exacerbation. EurRespir J. 2008; 31: 563-70.

8. He JQ, Foreman MG, Shumansky K. Associations of IL-6 polymorphisms with lung function decline and COPD. Thorax. 2009; 64: 698-704.

9. Inoue $\mathrm{Y}$, Kawayama T, Iwanaga T. High plasma brain natriuretic peptide levels in stable COPD without pulmonary hypertension or Corpulmonale. Intern Med. 2009; 48: 503-12.

10. Papaioannou AI, Mazioti A, Kiropoulos T, Tsilioni I, Koutsokera A, Tanou K, et al. Systemic and airway inflammation and the presence of emphysema in patients with COPD. Respir Med. 2010; 104(2): 275-82. doi: 10.1016/ j.rmed.2009.09.016

11. Pinto-Plata VM, Müllerova H, Toso JF, Feudjo-Tepie M, Soriano JB, Vessey RS, et al. C-reactive protein in patients with COPD, control smokers and non-smokers. Thorax. 2006; 61(1): 23-8.

12. Comes A, lanoși ES, Jimborean G. Inflammatory Biomarkers in Chronic Obstructive Pulmonary Disease. Journal of Interdisciplinary Medicine. 2016; 1(1): 12-7.

13. de Torres JP, Pinto-Plata V, Casanova C, Mullerova H, Córdoba-Lanús E, de Fuentes MM, et al. C-reactive protein levels and survival in patients with moderate to very severe COPD. Chest. 2008; 133(6): 1336-43. doi: 10.1378/ chest.07-2433

14. Alavi SA, Soati F, Forghanparast K, Amani H. HsCRP in Patients with Acute Exacerbation of Chronic Obstructive Pulmonary Disease. Iran Red Crescent Med J. 2011; 13(10): 713-8.

15. Deng ZC, Zhao P, Cao C, Sun SF, Zhao F, Lu CY, et al. C-reactive protein as a prognostic marker in chronic obstructive pulmonary disease. Exp Ther Med. 2014; 7(2): 443-6.

16. Leuzzi G, Galeone C, Taverna F, Suatoni P, Morelli D, Pastorino U. C-reactive protein level predicts mortality in COPD: a systematic review and meta-analysis. Eur Respir Rev. 2017; 26(143): 160-70. doi: 10.1183/16000617.0070-2016

17. Koul PA. Metabolic syndrome and chronic obstructive pulmonary disease. Lung India. 2016; 33: 359-61.

18. Agustí A, Edwards LD, Rennard SI, MacNee W, Tal-Singer R, Miller BE, et al. Persistent systemic inflammation is associated with poor clinical outcomes in COPD: a novel phenotype. PLoS One. 2012; 7(5): e37483. doi: 10.1371/ journal.pone.0037483

19. Agarwal R, Zaheer MS, Ahmad Z, Akhtar J. The relationship between C-reactive protein and prognostic factors in chronic obstructive pulmonary disease. Multidiscip. Respir. Med. 2013; 8 (1): 63. doi:10.1186/2049-6958-8-63

20. Savchenko L, Mykytiuk M, Cinato M, Tronchere H, Kunduzova O, Kaidashev I. IL-26 in the induced sputum is associated with the level of systemic inflammation, lung functions and body weight in COPD patients. Int $J$ Chron Obstruct Pulmon Dis. 2018; 13: 2569-75. doi: 10.2147/COPD.S164833

21. Breyer MK, Spruit MA, Celis AP, Rutten EP, Janssen PP, Wouters EF. Highly elevated C-reactive protein levels in obese patients with COPD: a fat chance? Clin Nutr. 2009; 28(6): 642-7. doi: 10.1016/j.clnu.2009.05.005

22. Pahlavani M, Ramalho T, Koboziev I, LeMieux MJ, Jayarathne S, Ramalingam L, et al. Adipose tissue inflammation in insulin resistance: review of mechanisms mediating anti-inflammatory effects of omega-3 polyunsaturated fatty acids. J Investig Med. 2017; 65(7): 1021-7. doi: 10.1136/jim-2017-000535

23. Tkacova R. Systemic Inflammation in chronic obstructive pulmonary disease: May adipose tissue play a role? Review of the literature and future perspectives. Hindawi Publishing Corporation. Mediators Inflamm. 2010; Apr 20. doi: $10.1155 / 2010 / 585989$

24. Leivo-Korpela S. Adipokines in Inflammatory Lung Diseases [academic dissertation]. Tampere: University of Tampere, School of Medicine Tampere University Hospital Finland; 2014. 121 p.

25. Zhuravleva LV, Rogacheva TA. Ozhirenie kak multidistsiplinarnaya problema-klinika, diagnostika, lechenie. Skhidnoyevropeyskyy zhurnal vnutrishnoyi ta simeynoyi medytsyny. 2017; 2: 31-5. doi: 10.15407/internalmed2017.02.031 [Russian]

26. Kolasa-Trela R, Miszalski-Jamka T, Grudzień G, Wypasek E, Kostkiewicz M. Adiponectin, leptin, and resistin in patients with aortic stenosis without concomitant atherosclerotic vascular disease. Pol Arch Med Wewn. 2011; 121(10): 352-60. 
27. Kumor-Kisielewska A, Kierszniewska-Stępień D, Pietras T, Kroczyńska-Bednarek J, Kurmanowska Z, Antczak A, et al. Assessment of leptin and resistin levels in patients with chronic obstructive pulmonary disease. Pol Arch Med Wewn. 2013; 123(5): 215-20.

28. Martin SS, Qasim A, Reilly MP. Leptin resistance: a possible interface of inflammation and metabolism in obesityrelated cardiovascular disease. J Am Coll Cardiol. 2008; 52: 1201-10.

29. Bruno A, Chanez P, Chiappara G, Siena L, Giammanco S, Gjomarkaj M, et al. Does leptin play a cytokine-like role within the airways of COPD patients? Eur Respir J. 2005; 26(3): 398-405. doi: 10.1183/09031936.05.00092404

30. Broekhuizen R, Wouters EF, Creutzberg EC, Weling-Scheepers CA, Schols AM. Polyunsaturated fatty acids improve exercise capacity in chronic obstructive pulmonary disease. Thorax. 2005; 60(5): 376-82.

31. Ahmad EM, Magdy MO, Nabi AA. Leptin hormone in obese and non-obese stable and exacerbated cases of chronic obstructive pulmonary disease. Egypt J Chest Dis Tuberc. 2015; 64(3): 557-65.

32. Vernooy JH, Drummen NE, van Suylen RJ, Cloots RH, Möller GM, Bracke KR, et al. Enhanced pulmonary leptin expression in patients with severe COPD and asymptomatic smokers. Thorax. 2009; 64(1): 26-32. doi: 10.1136/ thx.2007.085423

33. Broekhuizen R, Vernooy JH, Schols AM, Dentener MA, Wouters EFM. Leptin as local inflammatory marker in COPD. Respir Med. 2005; 99(1): 70-4.

34. Takabatake N, Nakamura H, Abe S, Hino T, Saito H, Yuki H, et al. Circulating leptin in patients with chronic obstructive pulmonary disease. Am J Respir Crit Care Med. 1999; 159(4(1)): 1215-9.

35. Calikoglu M, Sahin G, Unlu A, Ozturk C, Tamer L, Ercan B, et al. Leptin and TNF-alpha levels in patients with chronic obstructive pulmonary disease and their relationship to nutritional parameters. Respiration. 2004; 71(1): 45-50.

36. Pamir N, McMillen TS, Kaiyala KJ, Schwartz MW, LeBoeuf RC. Receptors for tumor necrosis factor-alpha play a protective role against obesity and alter adipose tissue macrophage status. Endocrinology. 2009; 150(9): 4124-34. doi: 10.1210/en.2009-0137

37. Hansel NN, Gao L, Rafaels NM, Mathias RA, Neptune ER, Tankersley C, et al. Leptin receptor polymorphisms and lung function decline in COPD. Eur Respir J. 2009; 34(1): 103-10. doi: 10.1183/09031936.00120408

38. Radchenko O, Pylypiv L, Zukow W. Lung function testing according leptin levels in patients with chronic obstructive pulmonary disease. J Education Health and Sport. 2017; 7(3): 231-8.

\section{УДК 616.24-002-056.5}

\section{МАРКЕРИ СИСТЕМНОГО ЗАПАЛЕННЯ У ХВОРИХ НА ХОЗЛ У ПОЄДНАННІ 3 ОЖИРІННЯМ}

\section{Кузнєцова Л. П., Гопко О. Ф., Савченко Л. В.}

Резюме. Одним з найбільш розповсюджених захворювань органів дихання залишається хронічне обструктивне захворювання легень при якому коморбідну патологію виявляють майже у 90 \% хворих. Особливої уваги у клініці внутрішньої медицини заслуговує поєднання з аліментарним ожирінням за рахунок наступних факторів ризику: постаріння населення, гіподинамія, надмірне харчування, що сприяє прогресуванню коморбідної патології та розвитку ускладнень.

Хронічний запальний процес $є$ головною ланкою патогенезу хронічного обструктивного захворювання легень, що викликає структурні зміни дихальних шляхів і легень (бронхіальна обструкція та втрата еластичності паренхіми легень) на тлі системного запалення, особливо у пацієнтів з надмірною вагою. Тому метою роботи було провести аналіз літературних даних про найбільш поширені маркери системного запалення у хворих на хронічне обструктивне захворювання легень із ожирінням.

Високочутливий С-реактивний протеїн являє собою гострофазний білок, що синтезується гепатоцитами у відповідь на ушкодження бронхолегеневої тканини внаслідок запального процесу. Доведений тісний зворотний зв'язок між показниками високочутливого С-реактивного протеїну та функціональними показниками вентиляційної здатності легень, клінічними показниками тяжкості хронічного обструктивного захворювання легень.

Жирова тканина розглядається як ендокринний орган і джерело біологічно активних речовин - адипокінів, біоактивних пептидів, вільних жирних кислот, моноцитарного хемотаксичного фрактору-1 (моноцитарний хемотаксичний білок-1-МСР-1), прозапальних цитокінів, що приймають участь в системному запаленні низької інтенсивності при багатьох патологічних станах, в тому числі при захворюваннях органів дихання. Вивченню лептину як плейотропного гормону, який визначає стан імунного гомеостазу та ангіогенезу присвячена велика кількість робіт. Однак важливим відкриттям стало визначення ролі лептину в ураженні органів дихання, враховуючи що лептин $є$ стимулятором вентиляції, фрактором визначаючим процеси дозрівання та розвитку легень, а також респіраторних захворювань, включаючи обструктивний синдром нічного апное, бронхіальну астму, хронічне обструктивне захворювання легень та рак легень. 
Отже, високочутливий С-реактивний протеїн та лептин є загальними біомаркерами системного запалення низької інтенсивності, котрі можна використовувати для оцінки ступеня тяжкості хронічного обструктивного захворювання легень та ожиріння.

Ключові слова: хронічне обструктивне захворювання легень, ожиріння, високочутливий Среактивний протеїн, лептин.

УДК 616.24-002-056.5

МАРКЕРЫ СИСТЕМНОГО ВОСПАЛЕНИЯ У БОЛЬНЫХ ХОБЛ В СОЧЕТАНИИ С ОЖИРЕНИЕМ Кузнецова Л. Ф., Гопко А. Ф., Савченко Л. В.

Резюме. Одним из самых распространенных заболеваний органов дыхания остается хроническая обструктивная болезнь легких, при которой коморбидную патологию выявляют почти у 90\% больных. Особое внимание в клинике внутренней медицины заслуживает сочетание с алиментарным ожирением за счет следующих фракторов риска: старение населения, гиподинамия, избыточное питание, что способствует прогрессированию коморбидной патологии и развитию осложнений.

Хронический воспалительный процесс является главным звеном патогенеза хронической обструктивной болезни легких, вызывает структурные изменения дыхательных путей и легких (бронхиальная обструкция и потеря эластичности паренхимы легких) на фоне системного воспаления, особенно у пациентов с избыточным весом. Поэтому целью работы было провести анализ литературных данных о наиболее распространенных маркерах системного воспаления у больных хронической обструктивной болезнью легких с ожирением.

Высокочувствительный С-реактивный протеин представляет собой острофазный белок, синтезируемый гепатоцитами в ответ на повреждение бронхолегочной ткани вследствие воспалительного процесса. Доказана тесная обратная связь между показателями высокочувствительного С-реактивного протеина и функциональными показателями вентиляционной способности легких, клиническими показателями тяжести хронической обструктивной болезни легких.

Жировая ткань рассматривается как эндокринный орган и источник биологически активных веществ - адипокинов, биоактивных пептидов, свободных жирных кислот, моноцитарного хемотаксического фрактора-1 (моноцитарный хемотаксический белок-1-МСР-1), провоспалительных цитокинов, участвующих в системном воспалении низкой интенсивности при многих патологических состояниях, в том числе при заболеваниях органов дыхания. Изучению лептина как плейотропного гормона, который определяет состояние иммунного гомеостаза и ангиогенеза посвящено большое количество работ. Однако важным открытием стало определение роли лептина в поражении органов дыхания, учитывая, что лептин является стимулятором вентиляции, фактором, определяющим процессы созревания и развития легких, а также респираторных заболеваний, включая обструктивный синдром ночного апноэ, бронхиальную астму, хроническая обструктивная болезнь легких и рак легких.

Таким образом, высокочувствительный С-реактивный протеин и лептин являются общими биомаркерами системного воспаления низкой интенсивности, которые можно использовать для оценки степени тяжести хронической обструктивной болезни легких и ожирения.

Ключевые слова: хроническая обструктивная болезнь легких, ожирение, высокочувствительный Среактивный протеин, лептин.

The authors of this study confirm that the research and publication of the results were not associated with any conflicts regarding commercial or financial relations, relations with organizations and/or individuals who may have been related to the study, and interrelations of coauthors of the article. 